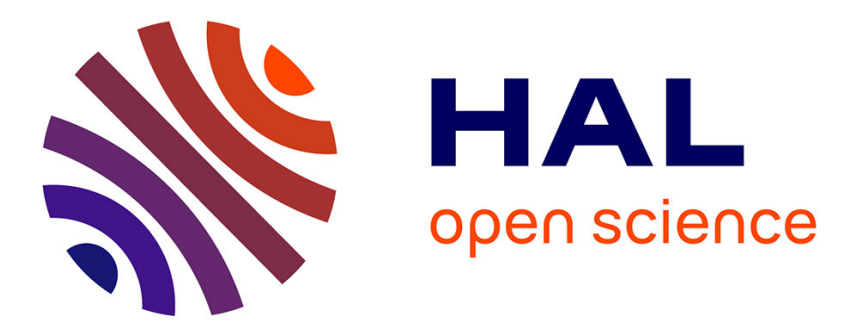

\title{
Methionine transsulfuration is increased during sepsis in rats
}

Thierry Malmezat, Denis Breuillé, Corinne Pouyet, Caroline Buffière, Philippe Denis, Philippe Patureau-Mirand, Christiane Obled

\section{- To cite this version:}

Thierry Malmezat, Denis Breuillé, Corinne Pouyet, Caroline Buffière, Philippe Denis, et al.. Methionine transsulfuration is increased during sepsis in rats. AJP - Endocrinology and Metabolism, 2000, 279 (6), pp.E1391-E1397. hal-02695983

\section{HAL Id: hal-02695983 \\ https://hal.inrae.fr/hal-02695983}

Submitted on 1 Jun 2020

HAL is a multi-disciplinary open access archive for the deposit and dissemination of scientific research documents, whether they are published or not. The documents may come from teaching and research institutions in France or abroad, or from public or private research centers.
L'archive ouverte pluridisciplinaire HAL, est destinée au dépôt et à la diffusion de documents scientifiques de niveau recherche, publiés ou non, émanant des établissements d'enseignement et de recherche français ou étrangers, des laboratoires publics ou privés. 
Thierry Malmezat, Denis Breuillé, Corinne Pouyet, Caroline Buffière, Philippe Denis, Philippe Patureau Mirand and Christiane Obled

Am J Physiol Endocrinol Metab 279:1391-1397, 2000.

You might find this additional information useful...

This article cites 27 articles, 12 of which you can access free at:

http://ajpendo.physiology.org/cgi/content/full/279/6/E1391\#BIBL

This article has been cited by 6 other HighWire hosted articles, the first 5 are:

Methionine-Adequate Cysteine-Free Diet Does Not Limit Erythrocyte Glutathione

Synthesis in Young Healthy Adult Men

G. Courtney-Martin, M. Rafii, L. J. Wykes, R. O. Ball and P. B. Pencharz

J. Nutr., November 1, 2008; 138 (11): 2172-2178.

[Abstract] [Full Text] [PDF]

Intrauterine bacterial inoculation and level of dietary methionine alter amino acid metabolism in nulliparous yearling ewes

T. M. Thelen, C. A. Loest, J. B. Taylor, S. Wang and G. S. Lewis

J Anim Sci, December 1, 2007; 85 (12): 3371-3382.

[Abstract] [Full Text] [PDF]

Methionine transmethylation and transsulfuration in the piglet gastrointestinal tract

M. A. Riedijk, B. Stoll, S. Chacko, H. Schierbeek, A. L. Sunehag, J. B. van Goudoever and D.

G. Burrin

PNAS, February 27, 2007; 104 (9): 3408-3413.

[Abstract] [Full Text] [PDF]

The Global Regulator Spx Functions in the Control of Organosulfur Metabolism in Bacillus subtilis

S.-Y. Choi, D. Reyes, M. Leelakriangsak and P. Zuber

J. Bacteriol., August 15, 2006; 188 (16): 5741-5751.

[Abstract] [Full Text] [PDF]

The Effects of Sulfur Amino Acid Intake on Immune Function in Humans

R. F. Grimble

J. Nutr., June 1, 2006; 136 (6): 1660S-1665S.

[Abstract] [Full Text] [PDF]

Medline items on this article's topics can be found at http://highwire.stanford.edu/lists/artbytopic.dtl on the following topics:

Biochemistry .. Cysteine

Biochemistry .. Methionine

Microbiology .. Escherichia Coli

Medicine .. Sepsis

Physiology .. Rats

Updated information and services including high-resolution figures, can be found at:

http://ajpendo.physiology.org/cgi/content/full/279/6/E1391

Additional material and information about AJP - Endocrinology and Metabolism can be found at: http://www.the-aps.org/publications/ajpendo

This information is current as of September 3, 2010 .

AJP - Endocrinology and Metabolism publishes results of original studies about endocrine and metabolic systems on any level of organization. It is published 12 times a year (monthly) by the American Physiological Society, 9650 Rockville Pike, Bethesda MD 20814-3991. Copyright @ 2000 by the American Physiological Society. ISSN: 0193-1849, ESSN: 1522-1555. Visit our website at http://www.the-aps.org/. 


\title{
Methionine transsulfuration is increased during sepsis in rats
}

\author{
THIERRY MALMEZAT, ${ }^{1}$ DENIS BREUILLÉ, ${ }^{2}$ CORINNE POUYET,${ }^{2}$ CAROLINE BUFFIÈRE,${ }^{2}$ \\ PHILIPPE DENIS, ${ }^{2}$ PHILIPPE PATUREAU MIRAND, ${ }^{1}$ AND CHRISTIANE OBLED ${ }^{1}$ \\ ${ }^{1}$ Laboratoire d'Etude du Métabolisme Azoté, Institut National de la Recherche Agronomique, \\ Clermont-Ferrand-Theix, 63122 Saint Genès Champanelle, France; \\ and ${ }^{2}$ Centre de Recherches Nestlé, Vers chez les blanc, Lausanne 26, Switzerland
}

Received 20 April 2000; accepted in final form 24 August 2000

\begin{abstract}
Malmezat, Thierry, Denis Breuillé, Corinne Pouyet, Caroline Buffière, Philippe Denis, Philippe Patureau Mirand, and Christiane Obled. Methionine transsulfuration is increased during sepsis in rats. Am J Physiol Endocrinol Metab 279: E1391-E1397, 2000.-Methionine transsulfuration in plasma and liver, and plasma methionine and cysteine kinetics were investigated in vivo during the acute phase of sepsis in rats. Rats were infected with an intravenous injection of live Escherichia coli, and control pair-fed rats were injected with saline. Two days after injection, the rats were infused for $6 \mathrm{~h}$ with $\left[{ }^{35} \mathrm{~S}\right]$ methionine and $\left[{ }^{15} \mathrm{~N}\right]$ cysteine. Transsulfuration was measured from the transfer rate of ${ }^{35} \mathrm{~S}$ from methionine to cysteine. Liver cystathionase activity was also measured. Infection significantly increased $(P<0.05)$ the contribution of transsulfuration to cysteine flux in both plasma and liver (by $80 \%$ ) and the contribution of transsulfuration to plasma methionine flux (by 133\%). Transsulfuration measured in plasma was significantly $(P<0.05)$ higher in infected rats than in pair-fed rats $(0.68$ and 0.25 $\mu \mathrm{mol} \cdot \mathrm{h}^{-1} \cdot 100 \mathrm{~g}^{-1}$, respectively). However, liver cystathionase specific activity was decreased by $17 \%$ by infection $(P<$ $0.05)$. Infection increased methionine flux $(16 \%, P<0.05)$ less than cysteine flux $(38 \%, P<0.05)$. Therefore, the plasma cysteine flux was higher than that predicted from estimates of protein turnover based on methionine data, probably because of enhanced glutathione turnover. Taken together, these results suggest an increased cysteine requirement in infection.
\end{abstract}

methionine flux; cystathionase; components of cysteine flux

TRAUMA AND SEPSIS markedly alter metabolism, and particularly amino acid and protein metabolism (33). The roles of protein synthesis and breakdown in mediating the response of whole body protein economy after injury have been extensively studied. A net catabolism of protein occurs primarily in muscle, and the amino acids are used to increase synthesis of proteins, including acute-phase proteins and proteins of the immune system $(5,23)$. However, the metabolism of individual amino acids, especially methionine and cysteine, has received less attention despite their important roles. Methionine participates in methyl group metabolism

\footnotetext{
Address for reprint requests and other correspondence: C. Obled, Laboratoire d'Etude du Métabolisme Azoté, INRA, Clermont-Ferrand Theix, 63122 Saint Genès Champanelle, France (E-mail: obled @clermont.inra.fr).
}

and synthesis of polyamines, creatine, and other sulfur amino acids, notably cysteine (8). Cysteine is required for the synthesis of glutathione and taurine, which are important compounds for host defense against oxidative stress $(19,34)$.

Cysteine is formed principally in the liver by transsulfuration from methionine to serine. The transsulfuration is initiated by the conversion of homocysteine, formed by transmethylation of methionine, into cystathionine by cystathionine synthase. Cystathionine is in turn converted into cysteine and 2-ketobutyrate by cystathionase (8). Under normal circumstances, this pathway constitutes a significant source of cysteine, and cysteine is appropriately called nonindispensable. However, in certain clinical conditions, cysteine biosynthesis is altered, and a diminished supply of cysteine may reduce its further metabolism and the synthesis of important metabolites. In cirrhotics, methionine utilization and cysteine biosynthesis are impaired, and a source of cysteine has been suggested as a necessary component of the cirrhotic diet (6). In premature infants, hepatic cystathionase is absent or in low concentration, leading to decreased cysteine plasma levels and glutathione synthesis rates in these subjects (31). In rats exposed to surgical stress, cystathionase activity was reduced by $\sim 40 \%$, inducing a low rate of cysteine synthesis in isolated hepatocytes (30). These data suggest that cysteine could be referred to as conditionally indispensable. Moreover, an exogenous supply of cysteine would be required for critically ill patients.

Methionine metabolism has been widely studied in healthy humans $(11,13,21,27,28)$. By contrast, to our knowledge, only one study has explored methionine kinetics in burn patients; that study showed an increased methionine flux and transsulfuration (35). The present study examines the influence of infection on methionine transsulfuration and methionine and cysteine kinetics, by use of labeled methionine and cysteine infusion. Because cystathionase is the limiting enzyme in methionine transsulfuration, its activity has

\footnotetext{
The costs of publication of this article were defrayed in part by the payment of page charges. The article must therefore be hereby marked "advertisement" in accordance with 18 U.S.C. Section 1734 solely to indicate this fact.
} 
been measured in liver. Because anorexia is a common feature of the response to infection, the study was performed in infected rats and control pair-fed rats.

\section{MATERIALS AND METHODS}

Animals and experimental design. Male Sprague-Dawley rats (Iffa Credo, Lyon, France), $\sim 250 \mathrm{~g}$ body weight, were individually housed in wire-bottom cages and received ad libitum a semi-liquid diet containing $12 \%$ protein, which has been described in detail previously (16). The amount of cys$\mathrm{t}(\mathrm{e})$ ine in the diet was $1.2 \mathrm{~g} / \mathrm{kg}$, and the amount of methionine was $4.7 \mathrm{~g} / \mathrm{kg}$. After an acclimatization of 5 days, rats were operated on as described previously (15). Briefly, a silicone catheter was inserted into the right jugular vein, and the free end of the catheter was tunneled subcutaneously and exteriorized dorsally on the head through a flexible spring secured to the top of the head with dental cement. The infusion line passed through the spring and was connected to a swivel suspended from the top of the cage, which allowed free movement of the rat. During a 7-day recovery period, the rats, which were continuously infused with saline at $0.1 \mathrm{ml} / \mathrm{h}$, had a growth rate of $6.09 \pm 0.96 \mathrm{~g} /$ day.

The rats were then injected via a tail vein with either live Escherichia coli $\left(4.3 \times 10^{8}\right.$ bacteria per rat, infected group, $n=8$ ) or saline (control group, $n=5$ ), as described previously $(5,16)$. Because infection induced a strong anorexia, control rats were pair-fed to the infected rats.

In the morning of the 2nd day after injection of bacteria or saline, food was withdrawn and a primed-continuous infusion of $\left[{ }^{15} \mathrm{~N}\right]$ cysteine [97 atom percent excess (APE); Cambridge Isotope Laboratories, Andover, MA] and $\left.{ }^{35} \mathrm{~S}\right]$ methionine ( $>37 \mathrm{TBq} / \mathrm{mmol}$, Amersham, Les Ullis, France) was started. The priming dose was $0.6 \mathrm{mg}$ of $\left[{ }^{15} \mathrm{~N}\right]$ cysteine and $6.4 \times 10^{7} \mathrm{dpm}$ of $\left.{ }^{35} \mathrm{~S}\right]$ methionine. The isotopes were continuously infused for $6 \mathrm{~h}$ at $0.6 \mathrm{ml} / \mathrm{h}, 0.9 \mathrm{mg} / \mathrm{h}$ for $\left[{ }^{15} \mathrm{~N}\right]$ cysteine and $6.4 \times 10^{7} \mathrm{dpm} / \mathrm{h}$ for $\left[{ }^{35} \mathrm{~S}\right]$ methionine. Blood samples were taken from a tail vein 5 and $5.5 \mathrm{~h}$ after the start of the infusion. At the end of the infusion, animals were anesthetized, and the liver was rapidly excised. The samples were frozen in liquid nitrogen and conserved at $-80^{\circ} \mathrm{C}$ until analysis.

The protocol was approved by The Ethics Committee of the Institute and was conducted in conformity with the principles described in the National Research Council's Guide for the Care and Use of Laboratory Animals.

Cystathionase activity. An aliquot of liver (the same lobe for each rat) was taken off immediately after exsanguination of the rat and homogenized in ice-cold buffer of $100 \mathrm{mM}$ potassium hydrogen-phosphate and $1 \mathrm{mM}$ EDTA, pH 7.0. Homogenates were centrifuged at $3,000 \mathrm{~g}$ and $4^{\circ} \mathrm{C}$ for $60 \mathrm{~min}$, and glycerol was added to $20 \%$ (vol/vol). The cystathionase activity was measured as described by Vina et al. (30). Dithiothreitol ( $5 \mu \mathrm{mol} /$ tube) was added to bring all cystine to the reduced form, and the amount of cysteine was determined by the spectrophotometric method of Gaitonde (12). The soluble protein concentration of tissue extracts was determined according to Smith et al. (25) by the colorimetric reaction with bicinchoninic acid.

Cystathionine concentrations. Liver and plasma samples were extracted in 8 volumes of ice-cold TCA $(0.6 \mathrm{M})$ containing $\beta$-mercaptoethanol $2.5 \%$ ( $\mathrm{vol} / \mathrm{vol}$ ). The soluble fraction containing amino acids was separated from the protein precipitate by centrifugation ( $20 \mathrm{~min}, 8,000 \mathrm{~g}$ ) and then chromatographed on cationic resin columns (resin AG50×8, 100200 mesh, hydrogen form, Bio-Rad). Amino acids eluted with $4 \mathrm{M} \mathrm{NH}_{4} \mathrm{OH}$ were dried and resuspended in $0.2 \mathrm{M}$ lithium citrate buffer, $\mathrm{pH}$ 2.2. Cystathionine concentration was determined with an amino acid analyzer (Alpha Plus, LKB, London, UK).

Plasma and liver methionine and cysteine specific radioactivities. Aliquots of plasma and liver were suspended in 1 vol of the mobile phase used thereafter in the HPLC procedure $(3.2 \mathrm{ml} / \mathrm{l} O$-phosphoric acid, $0.5 \mathrm{~g} / \mathrm{l}$ heptane sulfonic acid, 30 $\mathrm{ml} / \mathrm{l}$ methanol, $\mathrm{pH}$ 2.4) and ultrafiltered. Separation of methionine and cysteine-cystine in the ultrafiltrate was then carried out by reversed-phase liquid chromatography as detailed previously (16). Methionine concentration was measured with an electrochemical detector (Coulochem II, ESA, Eurosep, France) placed after the column. Fractions containing methionine or cysteine-cystine were collected, and radioactivity was determined using a liquid scintillation counter (Betamatic IV, Kontron). Cysteine-cystine concentration in the ultrafiltrate was determined by the method of Gaitonde (12).

Plasma cysteine enrichments. To $500 \mu \mathrm{l}$ of plasma were added $500 \mu \mathrm{l} 10 \mathrm{mM}$ dithiothreitol, and the $\mathrm{pH}$ was adjusted to 8-9. The mixture was left at room temperature for $20 \mathrm{~min}$ to recover cystine and cysteine bound to protein as free cysteine. Then, $2 \mathrm{ml}$ of $0.6 \mathrm{M}$ TCA were added. The acidsoluble fraction containing free amino acids was separated by centrifugation $\left(20 \mathrm{~min}, 4^{\circ} \mathrm{C}, 8,000 \mathrm{~g}\right)$, and TCA was removed by cation exchange chromatography (resin AG50X8, 100-200 mesh, hydrogen form, Bio-Rad). Amino acids, eluted with $4 \mathrm{M}$ $\mathrm{NH}_{4} \mathrm{OH}$, were dried and resuspended in $20 \mu \mathrm{l}$ acetonitrile + $15 \mu l$ ethanethiol $+20 \mu l N$-(tert-butyldimethylsilyl) $N$-methyltrifluoroacetamide. Cysteine enrichment was then measured with an HP 5890 gas chromatograph coupled with an HP 5972 organic mass spectrometer (Hewlett-Packard, Les Ullis, France).

Calculations. Plasma methionine flux was determined as follows

$$
F_{\text {Met }}=\mathrm{I}_{\text {Met }} / \mathrm{SA}_{\text {Met }}
$$

where $F_{\text {Met }}$ is the methionine flux ( $\left.\mu \mathrm{mol} / \mathrm{h}\right), \mathrm{I}_{\mathrm{Met}}$ is the infusion rate of $\left[{ }^{35} \mathrm{~S}\right]$ methionine $(\mathrm{dpm} / \mathrm{h})$, and $\mathrm{SA}_{\mathrm{Met}}$ is the methionine specific activity at steady state in plasma (dpm/ $\mu \mathrm{mol}$ ).

Plasma cysteine flux was determined as follows

$$
F_{\text {Cys }}=\mathrm{I}_{\text {Cys }} \times\left(\mathrm{E}_{\mathrm{tr}} / \mathrm{E}_{\mathrm{pl}}\right)
$$

where $F_{\text {Cys }}$ is the cysteine flux ( $\mu \mathrm{mol} / \mathrm{h}$ ), $\mathrm{I}_{\mathrm{Cys}}$ is the infusion rate of $\left[{ }^{15} \mathrm{~N}\right]$ cysteine $(\mu \mathrm{mol} / \mathrm{h}), \mathrm{E}_{\mathrm{tr}}$ is the enrichment of the cysteine tracer (97 APE), and $\mathrm{E}_{\mathrm{pl}}$ is the enrichment of cysteine at the steady state in plasma (APE).

Because $\left[{ }^{35} \mathrm{~S}\right]$ cysteine is produced from $\left[{ }^{35} \mathrm{~S}\right]$ methionine by the transsulfuration pathway, the percentage of total entry into the plasma or liver cysteine pool that originates from methionine, i.e., the contribution of transsulfuration to cysteine flux in plasma $\left(k_{\text {pl }}\right)$ and in liver $\left(k_{\text {liver }}\right)$ was calculated according to Shipley and Clark (24) as follows

$$
\begin{gathered}
k_{\mathrm{pl}}=100 \times \mathrm{SA}_{\mathrm{Cys}} / \mathrm{SA}_{\mathrm{Met}} \\
k_{\text {liver }}=100 \times \mathrm{SA}_{\mathrm{Cys} \cdot \text { liver }} / \mathrm{SA}_{\text {Met-liver }}
\end{gathered}
$$

where $\mathrm{SA}_{\mathrm{Cys}}$ and $\mathrm{SA}_{\mathrm{Met}}$ are the specific activities of [ $\left.{ }^{35} \mathrm{~S}\right]$ cysteine and $\left[{ }^{35} \mathrm{~S}\right]$ methionine in plasma, and $\mathrm{SA}_{\mathrm{Cys} \cdot \text { liver }}$ and $\mathrm{SA}_{\mathrm{Met} \cdot \mathrm{liver}}$ are the specific activities of $\left[{ }^{35} \mathrm{~S}\right]$ cysteine and $\left.{ }^{35} \mathrm{~S}\right]$ methionine, respectively, in liver.

In plasma, the rate of synthesis of cysteine from methionine, or transsulfuration, was calculated as follows

$$
\mathrm{TS}=F_{\mathrm{Cys}} \times k_{\mathrm{pl}}
$$

where $F_{\text {Cys }}$ is the cysteine flux calculated with $\left[{ }^{15} \mathrm{~N}\right]$ cysteine. 
Table 1. Effect of infection on food consumption and body weight losses

\begin{tabular}{cccccc}
\hline \hline \multicolumn{2}{c}{ Food Consumption, g/day } & & \multicolumn{2}{c}{ Body Weight Losses, $\mathrm{g}$} \\
\cline { 2 - 5 } \cline { 4 - 6 }-1 & Day 0 & Day 1 & & Day 1 & Day 2 \\
\hline
\end{tabular}

Pair-fed rats $22.1 \pm 3.2 \quad 5.3 \pm 0.1 \quad 9.4 \pm 0.1-25.0 \pm 2.2-24.6 \pm 1.7$ Infected rats $27.3 \pm 2.5 \quad 5.2 \pm 2.29 .3 \pm 2.5-24.6 \pm 4.4-29.9 \pm 4.5^{*}$

Values are means \pm SD. One group of rats $(n=8)$ was infected by an iv injection of live Escherichia coli $\left(4.3 \times 10^{8}\right)$. A control group $(n=5)$ was injected with saline and was pair-fed with the infected rats. Body weight losses for day 2 are those between day 0 and day 2. ${ }^{*} P<0.05$ vs. pair-fed rats.

In steady-state conditions, the flux is the sum of inputs or the sum of outputs. Hence, in the postabsorptive state

$$
F_{\text {Met }}=\mathrm{B}_{\text {Met }}+\mathrm{RM}=\mathrm{S}_{\text {Met }}+\mathrm{TM}
$$

where $B_{\mathrm{Met}}$ is the rate of methionine appearance from protein breakdown, $\mathrm{S}_{\mathrm{Met}}$ is the rate of methionine disappearance via nonoxidative metabolism, an index of the rate of protein synthesis, RM is the remethylation rate, and TM is the transmethylation rate. However, $\mathrm{TS}=\mathrm{TM}-\mathrm{RM}$, and

$$
F_{\text {Met }}=\mathrm{B}_{\text {Met }}=\mathrm{S}_{\text {Met }}+\mathrm{TS}
$$

Therefore, $\mathrm{S}_{\mathrm{Met}}$ is calculated from the difference between $F_{\text {Met }}$ and TS, and

$$
F_{\mathrm{Cys}}=\mathrm{B}_{\mathrm{Cys}}+\mathrm{TS}+\mathrm{I}_{\mathrm{Cys}}+\mathrm{B}_{\mathrm{GSH}}=\mathrm{S}_{\mathrm{Cys}}+\mathrm{S}_{\mathrm{GSH}}+\mathrm{C}_{\mathrm{Cys}}
$$

where $\mathrm{B}_{\mathrm{Cys}}$ and $\mathrm{B}_{\mathrm{GSH}}$ are the rates of cysteine appearance from protein breakdown and GSH breakdown, respectively; $\mathrm{I}_{\mathrm{Cys}}$ is the rate of $\left[{ }^{15} \mathrm{~N}\right]$ cysteine infusion; $\mathrm{S}_{\mathrm{Cys}}$ is the rate of cysteine disappearance via nonoxidative metabolism, an index of the rate of protein synthesis; $\mathrm{S}_{\mathrm{GSH}}$ is the rate of cysteine utilization for GSH synthesis; and $\mathrm{C}_{\mathrm{Cys}}$ is the rate of cysteine catabolism. $\mathrm{B}_{\mathrm{Cys}}$ and $\mathrm{S}_{\mathrm{Cys}}$ can be estimated from $\mathrm{B}_{\mathrm{Met}}$ and $\mathrm{S}_{\mathrm{Met}}$ by multiplying these values by the molar ratio of cysteine to methionine in average proteins in rat whole body. This ratio is assessed to be $1.36(20)$. Therefore $\mathrm{B}_{\mathrm{GSH}}$ is calculated from the difference between $F_{\text {Cys }}$ and (TS + $\left.\mathrm{B}_{\mathrm{Cys}}+\mathrm{I}_{\mathrm{Cys}}\right)$, and $\left(\mathrm{S}_{\mathrm{GSH}}+\mathrm{C}_{\mathrm{Cys}}\right)$ is calculated from the difference between $F_{\text {Cys }}$ and $\mathrm{S}_{\text {Cys. }}$

Statistics. Values are given as means $\pm \mathrm{SD}$. The nonparametric Mann-Whitney $U$-test was used to compare the infected with the pair-fed groups. A value of $P<0.05$ was accepted as statistically significant.

\section{RESULTS}

Food consumption, rat body weight, and liver weight. Before infection, rats consumed $\sim 25 \mathrm{~g}$ of dry matter per day (Table 1). On the day of infection, the diet was consumed mainly during the morning before the injection. One day after injection, animals ate only $\sim 35 \%$ of the amount consumed before injection of bacteria. On day 2 after injection, rats had no access to food, so they were in postabsorptive state during the infusion. Food intake restriction produced a body weight loss over the 2 days in control rats (Table 1). Nevertheless, infected animals lost more weight than pair-fed rats $(\sim 30$ and $\sim 24 \mathrm{~g}$, respectively, on day 2). Two days postinfection, liver weight of infected rats was significantly higher than that of pair-fed animals $(11.8 \pm 1.6$ and $8.9 \pm$ $1.2 \mathrm{~g}$, respectively, $P<0.05$ ).
Amino acid concentrations and cystathionase activity. Plasma cystathionine and methionine concentrations were significantly higher in septic rats than in pair-fed rats (34 and 12\%, respectively; Table 2). However, there was no difference in plasma cysteine + cystine levels (Table 2). As observed in the plasma, liver cystathionine concentration was significantly higher $(+80 \%)$ in septic rats than in pair-fed rats (Table 3). Because sepsis induced an increase of liver weight, total liver cystathionine content was much higher $(+136 \%)$ in whole livers of septic rats than in whole livers of pair-fed rats (Table 3). In whole liver, cysteine + cystine and methionine contents were similar in septic rats to those in pair-fed rats (Table 3 ). The whole liver content of total glutathione was significantly increased (45\%) by infection. Liver cystathionase activity was significantly lower (17\%) in infected rats, but whole liver cystathionase activity was not significantly different between infected and pair-fed rats (Table 3 ).

Cysteine and methionine metabolism. Steady-state conditions for plasma isotopic enrichments of the two tracers, $\left[{ }^{15} \mathrm{~N}\right]$ cysteine and $\left[{ }^{35} \mathrm{~S}\right]$ methionine, had been achieved within the duration of infusion (Fig. 1). Infection induced a significant increase of plasma methionine $(16 \%)$ and cysteine $(38 \%)$ fluxes in infected rats compared with pair-fed rats (Table 4).

Infection increased the ratio of $\left[{ }^{35} \mathrm{~S}\right]$ cysteine to $\left[{ }^{35} \mathrm{~S}\right]$ methionine specific radioactivities measured either in plasma or in liver, indicating an increased percentage of total entry into plasma or liver cysteine pool coming from methionine by transsulfuration or the contribution of transsulfuration to cysteine flux (Table 4). Because the plasma cysteine flux was measured, it was possible to calculate the amount of cysteine coming from methionine in plasma, i.e., transsulfuration, which was calculated to be 2.7 times greater in infected rats than in pair-fed rats. The percentage of methionine flux entering the transsulfuration pathway was more than doubled in infected rats compared with pair-fed animals (Table 5). Infection caused an increase of the amount of cysteine produced by protein breakdown and glutathione catabolism and of the amount of cysteine used for catabolism and glutathione synthesis (Table 5).

\section{DISCUSSION}

There have been few attempts to explore cysteine synthesis directly and quantitatively in pathological states, and the present study was developed to address this problem. Some data suggested that cysteine syn-

Table 2. Plasma amino acid concentrations of infected and pair-fed rats 2 days after infection

\begin{tabular}{lccc}
\hline \hline & Cystathionine & Cysteine and Cystine & Methionine \\
\hline Pair-fed rats & $0.7 \pm 0.1$ & $283 \pm 65$ & $36.5 \pm 4.6$ \\
Infected rats & $1.0 \pm 0.2^{*}$ & $267 \pm 57$ & $41.6 \pm 3.5^{*}$ \\
\hline
\end{tabular}

Values are means \pm SD expressed in $\mu \mathrm{mol} / \mathrm{l}$; nos. of rats and treatments are as in Table $1 . * P<0.05$ vs. pair-fed rats. 
Table 3. Liver sulfur amino acids and cystathionase activity 2 days after infection

\begin{tabular}{|c|c|c|c|c|c|}
\hline & $\begin{array}{l}\text { Cystathionine } \\
\mathrm{nmol} / \mathrm{g}\end{array}$ & $\begin{array}{c}\text { Cysteine }+ \text { Cystine } \\
\mathrm{nmol} / \mathrm{g}\end{array}$ & $\begin{array}{l}\text { Methionine } \\
\mathrm{nmol} / \mathrm{g}\end{array}$ & $\begin{array}{l}\text { Glutathione } \\
\mathrm{mmol} / \mathrm{g}\end{array}$ & $\begin{array}{c}\text { Cystathionase Activity } \\
\mu \mathrm{mol} \cdot 30 \mathrm{~min}^{-1} \cdot \mathrm{mg}^{-1} \text { protein }\end{array}$ \\
\hline Pair-fed rats & $15 \pm 5$ & $334 \pm 57$ & $83 \pm 20$ & $4.90 \pm 0.21$ & $0.92 \pm 0.17$ \\
\hline \multirow[t]{2}{*}{ Infected rats } & $28 \pm 4^{*}$ & $335 \pm 53$ & $83 \pm 19$ & $5.29 \pm 0.55$ & $0.76 \pm 0.07^{*}$ \\
\hline & $\mu \mathrm{mol} /$ liver & $\mu \mathrm{mol} /$ liver & $\mu \mathrm{mol} /$ liver & $\mathrm{mmol} /$ liver & $\mu \mathrm{mol} \cdot 30 \mathrm{~min}^{-1} \cdot$ liver $^{-1}$ \\
\hline Pair-fed rats & $0.14 \pm 0.05$ & $2.99 \pm 0.32$ & $0.75 \pm 0.24$ & $43.6 \pm 4.8$ & $602 \pm 111$ \\
\hline Infected rats & $0.33 \pm 0.07^{*}$ & $3.99 \pm 0.92$ & $0.98 \pm 0.22$ & $63.1 \pm 13.0 *$ & $665 \pm 89$ \\
\hline
\end{tabular}

Values are means \pm SD for 8 infected and 5 control rats. $* P<0.05$ vs. pair-fed rats.

thesis was impaired in rats after surgery. As the metabolic demand for cysteine is high in injury because of increased glutathione synthesis (15), this finding could lead to redefining the dietary recommendations for critically ill patients.

Cysteine synthesis from methionine in vivo in rats is poorly documented. Methionine cycle and transsulfuration were determined in humans under several conditions by use of a constant intravenous infusion of doubly labeled methionine $\left(\left[\right.\right.$ methyl $\left.-{ }^{2} \mathrm{H}_{3}\right]-$ and $\left[1-{ }^{13} \mathrm{C}\right]$ methionine $)(11,13,27,28)$. In these studies, methionine transsulfuration was determined indirectly by methionine oxidation measured from the rate of ${ }^{13} \mathrm{CO}_{2}$ appearance. In the present study, two labeled amino acids ( $\left[{ }^{35} \mathrm{~S}\right]$ methionine and $\left[{ }^{15} \mathrm{~N}\right]$ cysteine) were used to quantify methionine transsulfuration in septic rats and pair-fed rats, and transsulfuration was measured directly from the rate of synthesis of $\left[{ }^{35} \mathrm{~S}\right]$ cysteine. The method used requires steady-state conditions (24). Using $\left[{ }^{15} \mathrm{~N}\right]$ cysteine infusion, we showed that $\left[{ }^{15} \mathrm{~N}\right]$ cysteine enrichment plateaued in the plasma

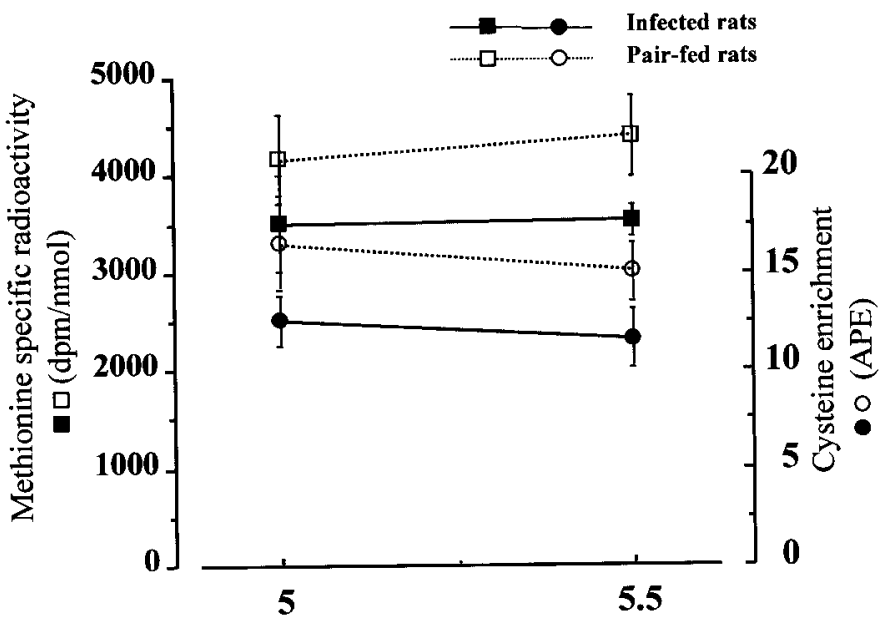

Time of infusion (h)

Fig. 1. Cysteine enrichment and methionine specific activity in plasma of infected and control pair-fed rats, 5 and $5.5 \mathrm{~h}$ after the beginning of the infusion. One group of rats was infected by an iv injection of live Escherichia coli $\left(4.3 \times 10^{8}\right)(n=8)$. A control group was injected with saline and pair-fed with the infected rats $(n=5)$. Two days after infection, rats were given a primed constant iv infusion of $\left[{ }^{35} \mathrm{~S}\right]$ methionine and $\left[{ }^{15} \mathrm{~N}\right]$ cysteine for $6 \mathrm{~h}$. Cysteine enrichment is expressed in atom percent excess (APE). Values are means $\pm \mathrm{SD}$. cysteine pool after $2 \mathrm{~h}$ of infusion (15). In the present study, we verified that plateau was maintained in plasma cysteine and methionine pools during the last hour of a 6 -h infusion (Fig. 1). The rate at which plateau is reached depends on the size of the free pool of the tracee and the turnover rate of the tissue, i.e., the fractional turnover rate of the tracee (32). Because the fractional turnover rate of plasma methionine is three times higher than that of cysteine, it could be expected that plateau could be reached more rapidly for methionine than for cysteine. Furthermore, it is likely that steady state in liver is reached at about the same time as in plasma because of the high turnover in this tissue (32).

In the present study, methionine transsulfuration accounted for only $3 \%$ of total plasma methionine flux and $1.6 \%$ of total plasma cysteine flux in pair-fed rats (Tables 4 and 5). However, the percentage of total entry into the cysteine pool coming from methionine was greater in liver than in plasma, reflecting its main localization in liver. However, the values in plasma seem low when compared with those obtained in humans, which, in the postabsorptive state, were $15-22 \%$ of methionine flux $(11,13,27,28)$ and $5-7 \%$ of cysteine flux $(11,13)$. Several causes could explain these discrepancies. The capacity for cysteine synthesis can be lower in rats than in humans. The methods used are also different. Measuring transsulfuration from the oxidation of methionine can overestimate this pathway, because methionine is also metabolized via a transamination-decarboxylation route. However, this

Table 4. Plasma methionine and cysteine fluxes 2 days after infection

\begin{tabular}{lcc}
\hline \hline & Pair-Fed Rats & Infected Rats \\
\hline & \multicolumn{2}{c}{$\%$} \\
Plasma Cys/Met specific activities $\left(k_{\mathrm{pl}}\right)$ & $1.55 \pm 0.44$ & $2.81 \pm 0.67^{*}$ \\
Liver Cys/Met specific activities $\left(k_{\text {liver }}\right)$ & $6.03 \pm 1.52$ & $11.0 \pm 2.6^{*}$ \\
& \multicolumn{1}{c}{$\mu \mathrm{mol} \cdot h^{-1} \cdot 100 \mathrm{~g}^{-1}$} \\
Methionine flux $\left(F_{\text {Met }}\right)$ & $7.79 \pm 0.50$ & $9.06 \pm 0.80^{*}$ \\
Cysteine flux $\left(F_{\text {Cys }}-\mathrm{I}_{\text {Cys }}\right)$ & $17.6 \pm 2.0$ & $24.1 \pm 3.5^{*}$ \\
Cysteine flux without tracer $\left(F_{\text {Cys }}\right)$ & $14.7 \pm 2.0$ & $21.2 \pm 3.3^{*}$ \\
Transsulfuration $(\mathrm{TS})$ & $0.25 \pm 0.08$ & $0.68 \pm 0.19^{*}$ \\
\hline
\end{tabular}

Values are means \pm SD. Two days after infection, rats were given a primed constant iv infusion of $\left[{ }^{35} \mathrm{~S}\right]$ methionine and $\left[{ }^{15} \mathrm{~N}\right]$ cysteine for 6 h. Cys/Met, ratio of Cys to Met. ${ }^{*} P<0.05$ vs. pair-fed rats. 
Table 5. Plasma methionine and cysteine fluxes 2 days after infection

\begin{tabular}{lll}
\hline \hline & Pair-Fed Rats & Infected Rats \\
\hline Methionine into proteins $\left(\mathrm{S}_{\mathrm{Met}}\right)$ & $7.55 \pm 0.57$ & $8.38 \pm 0.84$ \\
Transsulfuration/methionine flux, $\%$ & $3.23 \pm 1.18$ & $7.54 \pm 2.26^{*}$ \\
Cysteine from proteins $\left(\mathrm{B}_{\mathrm{Cys}}\right)$ & $10.6 \pm 0.7$ & $12.3 \pm 1.1^{*}$ \\
Cysteine from GSH $\left(\mathrm{B}_{\mathrm{GSH}}\right)$ & $3.89 \pm 2.45$ & $8.17 \pm 3.49^{*}$ \\
Cysteine into proteins $\left(\mathrm{S}_{\mathrm{Cys}}\right)$ & $10.3 \pm 0.8$ & $11.4 \pm 1.1$ \\
Cysteine into GSH + catabolism & & \\
$\left(\mathrm{S}_{\mathrm{GSH}}+\mathrm{C}_{\mathrm{Cys}}\right)$ & $7.31 \pm 2.63$ & $12.7 \pm 3.8^{*}$ \\
\hline
\end{tabular}

Values are means $\pm \mathrm{SD}$ expressed in $\mu \mathrm{mol} \cdot \mathrm{h}^{-1} \cdot 100 \mathrm{~g}^{-1}$. $* P<$ 0.05 vs. pair-fed rats.

route seems to be of minor importance in humans (3). It is also possible that our experimental conditions produce lower values. The rats were restricted in feed on the day before the metabolic study, which was performed in the postabsorptive state. Furthermore, the rats received no methionine during the infusion (radioactive methionine was given in trace amounts). On the other hand, stable isotopes are never infused in trace amounts, and the amount of labeled cysteine infused in this study $(6 \mathrm{mg})$ accounted for $\sim 53 \%$ of the intake of cysteine on day 1. It is well known that cysteine has a sparing effect on methionine by reduction of the transsulfuration pathway in rats $(9,26)$. Therefore, our conditions would favor a low transsulfuration rate.

Nevertheless, transsulfuration was measured under the same conditions in the two groups of rats, and our results clearly show that the synthesis of cysteine from methionine was higher in the infected animals than in the pair-fed rats (Table 4). Similar data were obtained in burn patients (35). However, the rate of cysteine synthesis from methionine determined in isolated hepatocytes was decreased after 3 days of stress induced by surgery in rats (30). This decrease was attributed to a decline of the activity of liver cystathionase, which is the limiting enzyme in the transsulfuration pathway. We report here that infection increased cysteine synthesis, despite inhibiting cystathionase activity, by $17 \%$ (Table 3 ). However, cystathionase activity was more reduced by surgical stress (30), and Rao et al. (22) showed that the production of cysteine was not significantly affected when the cystathionase activity was inhibited up to $63 \%$.

An accumulation of cystathionine was observed in plasma of premature infants due to cystathionase deficiency (31) and in plasma of rats treated with propargylglycine, a cystathionase inhibitor (7). By contrast, plasma and liver cystathionine concentrations were higher in infected rats than in pair-fed rats (Table 3). These results are in agreement with those of Rao et al. (22), who observed an accumulation of cystathionine at all levels of cystathionase inhibition, including those resulting in no reduction of cysteine synthesis. Infection generally induced no modification of total cysteine (free cysteine and cystine and protein-bound cysteine) and methionine concentrations in plasma and liver (Tables 2, 3), as generally found for plasma free cysteine and methionine in patients $(2,10,14,29)$. These results suggest that there is no impairment of the cystathionine pathway.

Total methionine and cysteine fluxes were higher in infected rats than in pair-fed rats (Table 4). Moreover, the methionine released from protein, but not the rate of incorporation of methionine into proteins, was significantly increased by infection (Table 5). These findings are in general agreement with those observed in injured patients by use of other amino acid tracers. Measurements of protein turnover in patients usually reveal an increase in whole body protein breakdown, with little or no increase in protein synthesis $(1,17,18$, 33 ), although the increase in protein breakdown is always greater than that in protein synthesis, leading to a negative nitrogen balance.

Cysteine flux was stimulated by infection more than methionine flux, suggesting a preferential utilization of cysteine during sepsis (Table 4). If we assume that the amino acid composition of whole body proteins is not modified by infection, the amount of cysteine used for protein synthesis or produced from protein breakdown can be calculated from the corresponding methionine data (Table 5). The part of cysteine flux not explained by protein turnover, which corresponds mainly to glutathione synthesis and cysteine catabolism, was greatly enhanced by infection in both absolute and relative terms (Fig. 2). We have shown previously that cysteine catabolism (sulfate production) was decreased 2 days after infection in rats (16). Taken together, these results indicate that glutathione synthesis was increased 2 days after infection, which is in keeping with our previous results demonstrating that glutathione turnover was stimulated during the acute phase of sepsis (15). Therefore, the increase of cysteine flux observed in sepsis is probably determined by the stimulation of glutathione turnover.

In conclusion, this study has shown that cysteine kinetics are profoundly altered by infection, with a decrease of the contribution of protein turnover. Cysteine synthesis from methionine is increased during
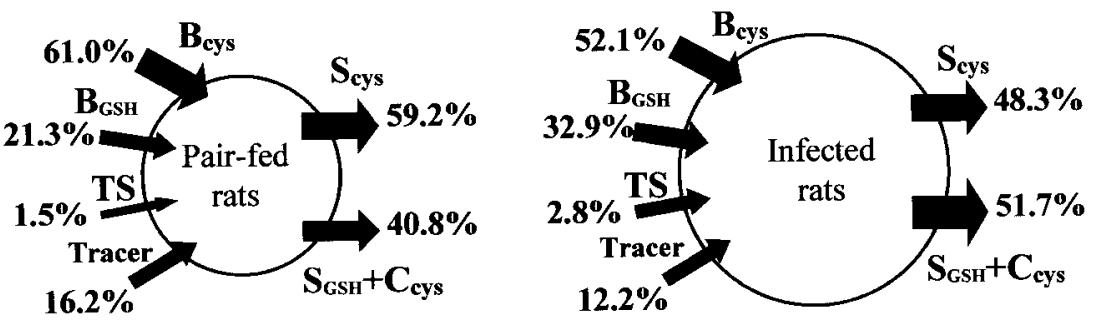

Fig. 2. Contribution of various pathways (\%) to cysteine plasma flux in infected and pair-fed rats. $\mathrm{S}_{\mathrm{Cys}}$, cysteine incorporated into proteins; $\mathrm{C}_{\mathrm{Cys}}$, cysteine catabolism; $\mathrm{S}_{\mathrm{GSH}}$, cysteine incorporated into glutathione; $\mathrm{B}_{\mathrm{Cys}}$, cysteine released from proteins; $\mathrm{B}_{\mathrm{GSH}}$, cysteine released from glutathione; TS, cysteine synthesis by transsulfuration. See MATERIALS AND METHODS for description of rat groups, treatments, and calculations. 
sepsis, both in absolute amounts and relative to methionine flux, in agreement with the results of $\mathrm{Yu}$ et al. (35) in burned patients. However, Yu et al. observed an increased activity of the various components of the methionine cycle in these patients, i.e., transmethylation and remethylation, with a relative reduction of homocysteine entering the transsulfuration pathway. This increased methionine cycle, probably due to increased methyl group transfer and utilization, can indicate enhanced requirements of various compounds, such as polyamines, choline, and carnitine. On the other hand, our results show that infection greatly enhances cysteine demand for glutathione synthesis (15). This increased utilization of cysteine can promote increased cysteine synthesis from methionine. However, taken together, these data suggest that a competition can exist at the homocysteine locus of methionine metabolism. Because cysteine synthesis is probably not sufficient to respond to the increased demand, a consequence would be additional depletion of body proteins to provide limiting amino acids. Therefore, an exogenous supply of cysteine could improve protein homeostasis and body defenses in critically ill patients. In septic rats, we have shown beneficial effects of cysteine supplementation on recovery, $\mathrm{N}$ balance, and muscle protein stores (4). Further metabolic and nutritional studies are needed to explore the importance of sulfur amino acid requirements in human patients.

We thank G. Bayle for amino acid measurements, P. Capitan for gas chromatography-mass spectrometry analysis, and D. Bonin and H. Lafarge for literature management.

This study was supported by the Institut National de la Recherche Agronomique, France, and by Nestec, Switzerland.

\section{REFERENCES}

1. Arnold J, Campbell IT, Samuels TA, Delvin JC, Green CJ, Hipkin LJ, MacDonald IA, Scrimgeour CM, Smith K, and Rennie MJ. Increased whole body protein breakdown predominates over increased whole body protein synthesis in multiple organ failure. Clin Sci (Colch) 84: 655-661, 1993

2. Askanazi J, Carpentier YA, Michelsen CB, Elwyn DH, Fürst P, Kantrowitz LR, Gump FE, and Kinney JM. Muscle and plasma amino acids following injury. Ann Surg 192: 78-85, 1980.

3. Blom HJ, Boers GHJ, Van Den Elzen JPAM, Gahl WA, and Tangerman A. Transamination of methionine in humans. Clin Sci (Colch) 76: 43-49, 1989.

4. Breuillé D, Arnal M, Buffière C, Denis $\mathbf{P}$, Pouyet $\mathbf{C}$, and Obled C. Beneficial effect of cysteine supplementation in response to sepsis. Clin Nutr 16: 17, 1997.

5. Breuillé D, Rosé F, Arnal M, Melin C, and Obled C. Sepsis modifies the contribution of different organs to whole-body protein synthesis in rats. Clin Sci (Colch) 86: 663-669, 1994

6. Chipponi JX, Bleier JC, Santi MT, and Rudman D. Deficiencies of essential and conditionally essential nutrients. Am $J$ Clin Nutr 35: 1112-1116, 1992.

7. Cho ES, Hovanec-Brown J, Tomanek RJ, and Stegink LD. Propargylglycine infusion effects on tissue glutathione levels, plasma amino acid concentrations and tissue morphology in parenterally-fed growing rats. J Nutr 121: 785-794, 1991.

8. Finkelstein JD. Methionine metabolism in mammals. J Nutr Biochem 1: 228-237, 1990

9. Finkelstein JD, Martin JJ, and Harris BJ. Effect of dietary cystine on methionine metabolism. J Nutr 116: 985-990, 1986.
10. Freund H, Atamian S, Holroyde J, and Fischer JE. Plasma amino acids as predictors of the severity and outcome of sepsis. Ann Surg 190: 571-576, 1979.

11. Fukagawa NK, Ajami AM, and Young VR. Plasma methionine and cysteine kinetics in response to an intravenous glutathione infusion in adult humans. Am $J$ Physiol Endocrinol Metab 270: E209-E214, 1996.

12. Gaitonde MK. A spectrophotometric method for the direct determination of cysteine in the presence of other naturally occurring amino acids. Biochem $J$ 104: 627-633, 1967.

13. Hiramatsu T, Fukagawa NF, Marchini JS, Cortiella J, Yu YM, Chapman TE, and Young VR. Methionine and cysteine kinetics at different intakes of cystine in healthy adult men. Am J Clin Nutr 60: 525-533, 1994.

14. Jeevanandam M, Young DH, Ramias L, and Schiller WR. Aminoaciduria of severe trauma. Am J Clin Nutr 49: 814-822, 1989

15. Malmezat T, Breuillé D, Capitan P, Patureau Mirand P, and Obled C. Increased glutathione turnover during the acute phase of sepsis. J Nutr 130: 1239-1246, 2000.

16. Malmezat T, Breuillé D, Pouyet C, Patureau Mirand P, and Obled C. Cysteine metabolism is modified during the acute phase of sepsis in rats. $J$ Nutr 128: 97-105, 1997.

17. Mansoor $\mathbf{O}$, Beaufrère $\mathbf{B}$, Boirie $\mathbf{Y}$, Rallière $\mathbf{C}$, Taillandier D, Aurousseau E, Schoeffler P, Arnal M, and Attaix D. Increased mRNA levels for components of the lysosomal, $\mathrm{Ca}^{2+}$. activated, and ATP-ubiquitin-dependent proteolytic pathways in skeletal muscle from head trauma patients. Proc Natl Acad Sci USA 93: 2714-2718, 1996.

18. Mansoor O, Cayol M, Gachon $\mathbf{P}$, Boirie $\mathbf{Y}$, Schoeffler $\mathbf{P}$, Obled C, and Beaufrère B. Albumin and fibrinogen syntheses increase while muscle protein synthesis decreases in head-injured patients. Am J Physiol Endocrinol Metab 273: E898-E902, 1997.

19. Meister A and Anderson ME. Glutathione. Annu Rev Biochem 52: 711-760, 1983.

20. Munro HN and Fleck A. Analysis of tissues and body fluids for nitrogenous constituents. In: Mammalian Protein Metabolism, edited by HN Munro. New York: Academic, 1969, vol 3, p. 508.

21. Raguso CA, Ajami AM, Gleason R, and Young VR. Effect of cystine intake on methionine kinetics and oxidation determined with oral tracers of methionine and cysteine in healthy adults. Am J Clin Nutr 66: 283-292, 1997.

22. Rao AM, Drake MR, and Stipanuk MH. Role of the transsulfuration pathway and of gamma-cystathionase activity in the formation of cysteine and sulfate from methionine in rat hepatocytes. J Nutr 120: 837-845, 1990.

23. Rooyackers OE, Saris WHM, Soeters PB, and Wagenmakers AJM. Prolonged changes in protein and amino acid metabolism after zymosan treatment in rats. Clin Sci (Colch) 87: $619-626,1994$

24. Shipley RA and Clark RE. Constant infusion of tracer. In: Tracer Methods for in vivo Kinetics. New York: Academic, 1972, p. $145-162$.

25. Smith PK, Krohn RI, Hermanson GT, Mallia AK, Gartner FH, Provenzano MD, Fujimoto EK, Goeke NM, Olson BJ, and Klenk DC. Measurement of protein using bicinchoninic acid. Anal Biochem 150: 76-85, 1985.

26. Stipanuk MA and Benevenga NJ. Effect of cysteine on the metabolism of methionine in rats. J Nutr 107: 1455-1467, 1977.

27. Storch KJ, Wagner DA, Burke JF, and Young VR. Quantitative study in vivo of methionine cycle in humans using [methyl- $\left.{ }^{2} \mathrm{H}_{3}\right]$ - and $\left[1{ }^{13} \mathrm{C}\right]$ methionine. Am J Physiol Endocrinol Metab 255: E322-E331, 1988 .

28. Storch KJ, Wagner DA, Burke JF, and Young VR. $\left[1^{-13} \mathrm{C}\right.$; methyl $-{ }^{2} \mathrm{H}_{3}$ ]methionine kinetics in humans: methionine conservation and cystine sparing. Am J Physiol Endocrinol Metab 258: E790-E798, 1990

29. Vente JP, Von Meyenfeldt MF, Eijk HMH, Van Berlo CLH, Gouma DJ, Van der Linden CJ, and Soeters PB. Plasma amino acid profiles in sepsis and stress. Ann. Surg 209: 57-62, 1989. 
30. Vina J, Gimenez A, Puertes IR, Gasco E, and Vina JR. Impairment of cysteine synthesis from methionine in rats exposed to surgical stress. Br J Nutr 68: 421-429, 1992.

31. Vina J, Vento M, Garcia-Sala F, Puertes IR, Gasco E, Sastre J, Asensi M, and Pallardo FV. L-Cysteine and glutathione metabolism are impaired in premature infants due to cystathionase deficiency. Am J Clin Nutr 61: 1067-1069, 1995.

32. Waterlow JC, Garlick PJ, and Millward DJ. Measurement of the site of incorporation of labelled amino acids into tissue proteins. In: Protein Turnover in Mammalian Tissues and in the Whole Body. Oxford, UK: North Holland, 1978, p. 339-370.

33. Wolfe RR, Jahoor F, and Hartl WH. Protein and amino acid metabolism after injury. Diabetes Metab Rev 5: 149-164, 1989.

34. Wright CE, Tallan HH, Lin YY, and Gaull GE. Taurine: biological update. Annu Rev Biochem 55: 427-453, 1986.

35. Yu YM, Burke JF, and Young VR. A kinetic study of $\mathrm{L}^{-}{ }^{2} \mathrm{H}_{3}-$ methyl-1- ${ }^{13} \mathrm{C}-$ methionine in patients with severe burn injury. J Trauma 35: 1-7, 1993.

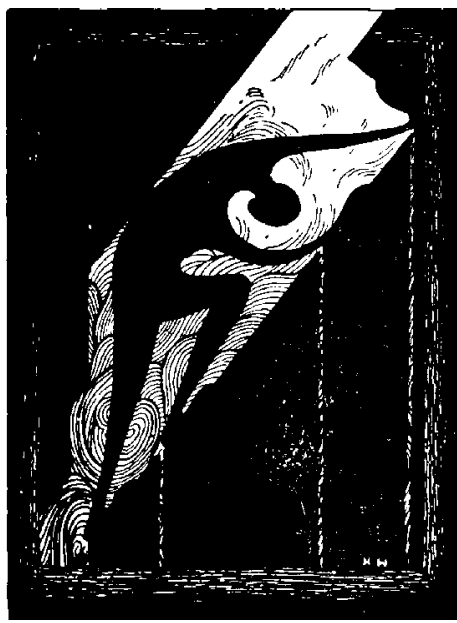

